\title{
PENGARUH EFEKTIVITAS PENGELOLAAN PNBP TERHADAP KINERJA KEUANGAN DI BADAN PENGEMBANGAN DAN PEMBINAAN BAHASA TAHUN 2018 - 2020
}

\author{
Edi Sarwasusila $^{1^{*}}$, Eko Sugiyanto ${ }^{2}$, Kumba Digdowiseiso ${ }^{2}$ \\ ${ }^{1}$ Pusat Pengembangan dan Pelindungan Bahasa dan Sastra \\ ${ }^{2}$ Program Studi Magister Administrasi Publik, Universitas Nasional \\ Email:edisarwasusila@gmail.com,ekoantodr@gmail.com, \\ kumba.digdo@civitas.unas.ac.id.
}

*Korespondensi: edisarwasusila@gmail.com.

(Submission 26-01-2021, Revissions 06-09-2021, Accepted 14-09-2021).

\begin{abstract}
This research aims to identify the effect of the effectiveness of PNBP management on financial performance in The Language Development and Fostering Agency (Badan Pengembangan dan Pembinaan Bahasa). The research methodology used in this research is a quantitative method. The instrument for collecting information uses a questionnaire. On the independent variable, the management effectiveness of $P N B P(X)$ and the dependent variable, financial performance in The Language Development and Fostering Agency (Y), each consists of 15 statement items. All 2 variable statements are valid because the $r_{\text {count }}$ and $r_{\text {tabel }}$ value, as well as all 2 variable statements are very reliable because they reach 0, 860 and 0, 961. The effect of the effectiveness of PNBP management on financial performance in The Language Development and Fostering Agency is sourced from the Pearson Correlation test showing a large value 0.249 (0.05), so it can be said that there is a correlation between the variable efficiency of PNBP management and financial performance variables, with a coefficient value of 0.354 , it can be seen that the variable efficiency of PNBP management $(X)$ has a positive effect on financial performance $(Y)$. With the subject of a positive direction, if there is an increase in the effectiveness of PNBP management by 1 unit, it will cause the turnover of financial performance to increase by 0,354 . Continuing to be good, the effectiveness of PNBP management continues to increase financial performance in The Language Development and Fostering Agency. The results of the product moment correlation analysis obtained a correlation coefficient of 0.249 and a coefficient of determination of 0.062 close to the maximum correlation coefficient $(1,000)$, so it can be interpreted that the degree of correlation between the effectiveness of PNBP management and financial performance lies in the large/tight type. On the other hand, the energy of determination/influence of the variable of utility in PNBP management on financial performance is real or significant.
\end{abstract}

Keywords: management efficiency of PNBP, financial performance, the effect of effectiveness, development agency, and language guidance. 


\begin{abstract}
Abstrak
Penelitian ini bertujuan untuk mengetahui pengaruh efektivitas pengelolaan PNBP terhadap kinerja keuangan di Badan Pengembangan dan Pembinaan Bahasa. Metodologi penelitian yang digunakan dalam penelitian ini adalah metode kuantitatif. Instrumen pengumpulan informasi menggunakan kuesioner. Pada variabel bebas, efektivitas pengelolaan PNBP (X) dan variabel terikat, kinerja keuangan Badan Pembinaan dan Pembinaan Bahasa (Y), masing-masing terdiri dari 15 item pernyataan. Kedua pernyataan variabel tersebut valid karena nilai rhitung dan rtabelnya, serta kedua pernyataan variabel tersebut sangat reliabel karena mencapai 0, 860 dan 0,961. Pengaruh efektivitas pengelolaan PNBP terhadap kinerja keuangan dalam Pengembangan Bahasa dan Badan Pembina bersumber dari uji Korelasi Pearson menunjukkan nilai besar 0,249 $(0,05)$, sehingga dapat dikatakan ada hubungan antara variabel efisiensi pengelolaan PNBP dengan variabel kinerja keuangan, dengan nilai koefisien sebesar 0,354, dapat diketahui bahwa variabel efisiensi pengelolaan PNBP (X) berpengaruh positif terhadap kinerja keuangan (Y) . Dengan subjek ke arah yang positif, jika terjadi peningkatan efektivitas pengelolaan PNBP sebesar 1 unit maka akan menyebabkan omset kinerja keuangan meningkat sebesar 0,354. Terus baik, efektivitas pengelolaan PNBP terus meningkat. meningkatkan kinerja keuangan di Badan Pembinaan dan Pembinaan Bahasa. Hasil analisis korelasi product moment diperoleh koefisien korelasi sebesar 0,249 dan koefisien determinasi sebesar 0,062 mendekati koefisien korelasi maksimum (1.000), sehingga dapat diartikan bahwa derajat korelasi antara efektivitas pengelolaan PNBP dengan kinerja keuangan terletak pada tipe besar/ketat. Sedangkan energi determinasi/pengaruh variabel utilitas dalam pengelolaan PNBP terhadap kinerja keuangan adalah nyata atau signifikan.
\end{abstract}

Kata Kunci: efisiensi pengelolaan PNBP, kinerja keuangan, pengaruh efektivitas, lembaga pembangunan, dan pembinaan bahasa.

\title{
PENDAHULUAN
}

Penerimaan Negara Bukan Pajak (untuk selanjutnya disebut PNBP) memegang peranan penting dan strategis dalam mendukung kebijakan pemerintah, terutama dalam hal pengendalian dan pengelolaan kekayaan negara, termasuk pemanfaatan sumber daya alam untuk mewujudkan kesejahteraan masyarakat, kemandirian bangsa dan pembangunan nasional yang berkelanjutan. Meskipun PNBP telah banyak memberikan kontribusi, tetapi pengelolaannya masih menghadapi permasalahan dan tantangan, antara lain adanya undang-undang sektoral yang mengatur tentang PNBP, seperti tarif dan penggunaan dana yang dinilai perlu disusun untuk mempertegas pengelolaan PNBP, dimana hal ini terkait dengan adanya pungutan tanpa dasar hukum, terlambat/tidak disetor ke kas negara, penggunaan langsung PNBP dan pengelolaanya di luar mekanisme APBN.

Peraturan Pemerintah Nomor 58 tahun 2020 tentang Pengelolaan PNBP telah menetapkan pengaturan terkait hak dan kewajiban Wajib Bayar dalam menjalankan kewajibannya kepada negara, misalnya hak wajib bayar yang dapat mengajukan koreksi surat tagihan, dan kewajiban wajib bayar dalam membayar PNBP sesuai waktu yang ditetapkan dan menyampaikan laporan PNBP. Pengaturan pengelolaan PNBP yang dituangkan dalam Peraturan Pemerintah ini terdiri atas: 
1. Perencanaan PNBP yang mengikuti siklus penyusunan Anggaran Pendapatan dan Belanja Negara;

2. Pelaksanaan PNBP yang mempertimbangkan manajemen pengelolaan PNBP yang profesional, transparan, dan akuntabel, serta memberikan kepastian hukum terhadap hak dan kewajiban Instansi Pengelola PNBP, Mitra Instansi Pengelola PNBP, dan Wajib Bayar.

3. Pertanggungjawaban PNBP yang memberikan gambaran atas proses perencanaan dan pelaksanaan PNBP;

4. Pengawasan PNBP yang mengatur kewenangan Aparat Pengawasan Intern Pemerintah dan Unit yang ditunjuk oleh Menteri dalam rangka meningkatkan kualitas perencanaan, pelaksanaan dan pertanggungjawaban.

Peraturan ini ditetapkan untuk meningkatkan kelancaran dan tertib administrasi dalam Pengelolaan PNBP yang sesuai dengan tujuan Undang-Undang Nomor 9 Tahun 2018 tentang Penerimaan Negara Bukan Pajak. Dengan demikian, tarif atas jenis PNBP ditetapkan dengan memperhatikan dampak dari pengenaan terhadap masyarakat dan kegiatan usahanya, biaya penyelenggaraan kegiatan pemerintah sehubungan dengan jenis PNBP yang bersangkutan, dan aspek keadilan dalam pengenaan beban kepada masyarakat.

Namun, dalam hal pengukuran kinerja keuangan yang dilakukan untuk mengetahui apakah suatu instansi menjalankan tugas dan fungsinya, sulit dilakukan secara obyektif. Hal ini dikarenakan pengukuran kinerja suatu instansi pemerintah lebih ditekankan pada kemampuan pada instansi pemerintah tersebut dalam melakukan penyerapan anggaran (Mahmudi, 2016). Karenanya, pengelolaan anggaran terutama PNBP dinilai mempunyai dua sisi anggaran. (Dinarjito, 2017) mengungkapkan ada beberapa penyebab permasalahan PNBP terlambat/belum disetor ke kas negara, PNBP kurang/tidak dipungut, memungut tanpa dasar hukum dan digunakan langsung, memungut dengan dasar hukum dan digunakan langsung, dan permasalahan lainnya.

(Masdiasmo, 2009) menyebutkan dalam melakukan penilaian kinerja instansi pemerintah, indikator yang diukur adalah: 1) penyimpangan antara realisasi anggaran dengan target yang telah ditetapkan; 2) efisiensi biaya; 3) efektivitas program, dan; 4) pemerataan keadilan. Ini berbeda dengan penilaian kinerja keuangan pada sektor publik, dimana prestasi diukur berdasarkan target yang telah ditetapkan dan pencapaian kinerja terhadap outcome dan output serta penganggaran yang efektif dan efisien, sehingga dapat dilakukan pengukuran kinerja dalam sektor publik.

(Dien A. N. J, et al, 2015) menyebutkan bahwa pimpinan dalam menilai capaian dari strategi yang telah ditetapkan melalui alat ukur finansial dan nonfinansial, dapat dijadikan sebagai alat pengendali organisasi, mengingat pengukuran kinerja diiringi dengan penetapan sistem reward dan punishment. Dengan demikian, kinerja bisa diartikan sebagai usaha yang dilakukan dalam pencapaian kinerja terhadap program, atau kegiatan dalam bentuk kebijakan yang dikeluarkan oleh instansi untuk mewujudkan visi dan misi, serta sasaran dari suatu organisasi instansi pemerintah sesuai dengan bidangnya. 
Bagi instansi pemerintah, visi dan misi yang diamanatkan adalah untuk kepentingan rakyat. Karena itu pengelolaan keuangan negara harus tertib sesuai dengan peraturan yang berlaku, efektif, efisien, transparan yang dapat dipertanggungjawabkan dalam keluarannya yang berupa output dan outcame dengan memperhatikan asas keadilan dan kepatuhan. Sehingga untuk mengukur tingkat keberhasilan program yang efektif dan efisien, dapat dilihat dari hasil capaian yang dapat memenuhi kebutuhan masyarakat dan pihak lain.

Badan Pengembangan dan Pembinaan Bahasa, Kementerian Pendidikan dan Kebudayaan, dalam penerapan sistem keuangannya mengacu pada Sistem Akuntansi Berbasis Akrual (SAIBA) pada tingkat Eselon I. Berdasarkan data yang dihimpun penulis pada Badan Pengembangan dan Pembinaan Bahasa, PNBP selama tiga tahun, atau tepatnya pada tahun 2018, 2019 dan per Juni 2020, berdasarkan Laporan Realisasi Anggaran Pendapatan yang melakukan pemungutan pendapatan ditemukan laporan sebagai berikut:

1) Pendapatan pada tahun 2018 sebesar Rp1.913.948.027,00 dengan persentasi sebesar 3,76\%;

2) Realisasi pendapatan tahun 2019 sebesar Rp3.340.819.094,00 dengan prosentase sebesar $16.56 \%$, dengan demikian bisa disebutkan mengalami kenaikan sebesar $12,80 \%$;

3) Realisasi pendapatan per juni 2020 sebesar Rp3.800.867.503,00 dengan prosentase sebesar $2,95 \%$, yang bisa disimpulkan bahwa dibanding prosentasi tahun 2019, angka ini mengalami penurunan sebesar $-14,00 \%$.

Beban target PNBP dinilai menjadi faktor penyebab penurunan pendapatan. Karena itu, dilakukan Pengajuan Usulan Pergantian Peraturan Pemerintah nomor 82 Tahun 2016 tentang Jenis dan Tarif atas Jenis Penerimaan Negara Bukan Pajak yang Berlaku pada Kementerian Pendidikan dan Kebudayaan. Usulan yang diajukan diantaranya adalah perlunya disiapkan informasi pendukung berbentuk TOR, RAB, justifikasi usulan, serta benchmark tarif, serta besaran kenaikannya tidak melebihi $100 \%$. Selain itu juga diusulkan perlunya membetulkan mutu tata kelola PNBP pada satuan kerja-satuan kerja penghasil, untuk secara intensif dilakukan pembinaan serta pengawasan melekat pada Satuan Kerja. Juga, diusulkan agar kegiatan penatausahan dijadikan sebagai dana PNBP yang dilakukan oleh pimpinan/petugas instansi/bendahara penerima dan bendaharawan pengguna yang ditunjuk, dan apabila pada akhir tahun terdapat saldo, wajib menyetorkan ke kas negara seluruhnya.

Berdasarkan data tersebut, bisa diasumsikan bahwa kinerja petugas pengelolaan PNBP pada Badan Pengembangan dan Pembinaan Bahasa belum menunjang outcome kinerja yang telah ditetapkan oleh Kementerian Pendidikan dan Kebudayaan yang akan menjadi tolok ukur dalam penentuan alokasi pendapatan pada tahun berikutnya. Selain itu, bisa pula diasumsikan bahwa kinerja keuangan dalam melakukan pengelolaan PNBP tidak efektif karena mengalami penurunan secara prosentase realisasi pendapatan.

Penelitian ini dilakukan untuk mengetahui: Apakah Efektivitas Pengelolaan PNBP di Badan Pengembangan dan Pembinaan Bahasa memiliki pengaruh terhadap Kinerja Keuangan instansi tersebut? Untuk mendukung fokus kajian, 
maka dirumuskan pula pertanyaan: Bagaimana Efektivitas Pengelolaan PNBP di Badan Pengembangan dan Pembinaan Bahasa, dan; Bagaimana Kinerja Keuangan di Badan Pengembangan dan Pembinaan Bahasa?

Dasar yang digunakan dalam penelitian adalah data yang diperoleh penulis, yaitu Laporan Realisasi Anggaran Pendapatan pada Badan Pengembangan dan Pembinaan Bahasa pada tahun 2018, 2019 dan per Juni 2020. Tujuan penelitian adalah untuk memotivasi instansi Badan Pengembangan dan Pembinaan Bahasa agar terus meningkatkan kinerjanya, dan menjadi sumber referensi bagi penelitian yang berkaitan dengan efektivitas pengelolaan APBN terhadap kinerja keuangan.

\section{Konsep dan Definisi}

\section{- Efektivitas}

Kata efektifitas merupakan wujud tidak baku dari kata daya guna sehingga penyusunan yang benar merupakan daya guna. Penyusunan kata yang benar dibunyikan dengan kata baku ialah kata yang penulisannya cocok dengan Kamus Besar Bahasa Indonesia (KBBI). Sedangkan kata efektif berasal dari Bahasa Inggris effective, maksudnya sukses; suatu yang dicoba dengan baik.

(Robbins, 1994) mendefinisikan daya guna sebagai tingkatan pencapaian organisasi jangka pendek serta jangka panjang. Daya guna mempunyai makna sukses ataupun pas guna. Efisien ialah kata dasar, sedangkan kata watak efisien merupakan daya guna. Menurut (Steers, 1977) pengertian efektivitas organisasi mempunyai arti berbeda pada setiap orang, tergantung pada kerangka acuan yang dipakai. Bagi seorang manager produksi, efektivitas sering kali diartikan sebagai kuantitas atau kualitas keluaran (output) barang atau jasa. Bagi seorang ilmuwan bidang riset, efektivitas dijabarkan dengan jumlah paten, penemuan atau produk baru suatu organisasi. Sedangkan (Effendy, 2003) menyatakan bahwa daya guna merupakan bagian dari komunikasi yang prosesnya direncanakan sedemikan rupa untuk mencapai tujuan yang diinginkan melalui mekanisme perencanaan baik dari segi waktu, anggaran dan jumlah sumber daya manusia yang menanganinya.

Bisa disimpulkan bahwa efektivitas berkaitan dengan pelaksanaan pekerjaan sesuai dengan tujuan yang telah ditetapkan, sedangkan efisiensi berkaitan dengan pelaksanaan kegiatan pekerjaan tersebut yang berdampak pada jumlah pembiayaan pekerjaan. Efektivitas juga terkait dengan pencapaian sasaran atau tujuan. Setiap pekerjaan yang dilakukan oleh individu, kelompok maupun organisasi memiliki tujuan tertentu. Tingkat pencapaian tujuan bisa dikatakan sebagai tingkat efektivitas. Jadi, efektivitas kerja merupakan pelaksanaan tugas dari suatu kegiatan dengan dilaksanakan menyesuaikan terhadap perencanaan yang telah ditetapkan.

\section{- Pengelolaan PNBP}

Undang-Undang nomor 9 tahun 2018 tentang Penerimaan Negara Bukan Pajak menyatakan PNBP ialah pungutan yang dibayar oleh orang-orang maupun badan dengan memperoleh manfaat langsung maupun tidak langsung seluruh pelayanan maupun pemanfaatan sumber energi alam dan hak yang diperoleh negeri, bersumber pada peraturan perundang- undangan, yang jadi penerimaan oleh 
pemerintah pusat di luar, penerimaan perpajakan dan hibah serta dikelola dalam mekanisme anggaran pendapatan dan belanja negara.

(Adetya, 2014) menyatakan bahwa penerimaan negara merupakan pendapatan yang diperoleh negara untuk membiayai dan menjalankan tiap programprogram pemerintahan. Sebaliknya, sumber-sumber penerimaan negara berasal dari bermacam sumber dan area, dimana seluruh hasil penerimaan tersebut hendak digunakan buat membiayai pembangunan serta tingkatkan kesejahteraan rakyat Indonesia. PNBP yang dikelola oleh Departemen/Lembaga Negara terdiri dari dua jenis, yaitu:

a) Jenis Umum

PNBP yang masuk jenis universal meliputi: (1) penerimaan kembali sisa anggaran tahun yang kemudian; (2) penerimaan hasil penjualan benda/kekayaan negara; (3) penerimaan hasil pemanfaatan benda/ kekayaan negara; (4) penerimaan hasil penyimpangan uang negara (jasa giro); (5) penerimaan ubah rugi atas kerugian negara (tuntutan ubah rugi serta tuntutan perbendaharaan), serta; (6) penerimaan denda keterlambatan ataupun kerjasama pembedahan.

b) Jenis Fungsional

PNBP yang masuk jenis fungsional meliputi: (1) penerimaan dari pembelajaran serta pelatihan yang sesuai dengan kedudukan serta fungsi satuan kerja; (2) penerimaan karcis masuk museum; (3) peneriman dari royalti penerbitan kamus; (4) penerimaan dari kontrak kerja sama yang cocok dengan kedudukan serta tugas satuan kerja; (5) penerimaan atas hasil penjualan produk serta penyelenggaraan pembelajaran; serta (6) penerimaan lainnya yang disahkan dengan peraturan perundang- undangan.

Markus (2005) mendefinisikan Penerimaan Negara Bukan Pajak (PNBP) sebagai segala penerimaan pemerintah pusat yang tidak berasal dari penerimaan pajak. PNBP merupakan seluruh penerimaan yang diterima oleh negara dalam wujud penerimaan dari sumber energi alam, bagian pemerintah atas laba usaha kepunyaan negar, dan penerimaan negara bukan pajak yang lain.

Undang-undang Nomor 20 Tahun 1997 perihal Penerimaan Negara Bukan Pajak pasal 2 ayat (1) menyebutkan bahwa Penerimaan Negara Bukan Pajak adalah:

1. Pendapatan yang bersumber dari pengelolaan dana pemerintah.

2. Pendapatan dari pemanfaatan sumber daya alam.

3. Pendapatan dari hasil-hasil pengelolaan kekayaan negara yang dipisahkan.

4. Pendapatan dari pelayanan yang dilaksanakan pemerintah.

5. Pendapatan berdasarkan putusan pengadilan dan yang berasal dari pengenaan denda administrasi; penerimaan berupa hibah yang merupakan hak pemerintah.

6. Pendapatan lainnya yang diatur dalam undang-undang tersendiri.

Dengan demikian, jenis PNBP yang tidak tercakup dalam kelompok sebagaimana terurai di atas, ditetapkan dengan Peraturan Pemerintah. Pengertian di luar jenis PNBP tersebut, dimungkinkan keberadaan PNBP lain melalui undangundang yang berlaku. Dapat disimpulkan bahwa efektivitas pengelolaan PNBP merupakan daya guna tingkatan pencapaian organisasi jangka pendek dan jangka 
panjang dalam penyelenggaraan PNBP kurun waktu yang sudah didetetapkan oleh lembaga ataupun organisasi dalam mendapatkan pemasukan negara yang bertabiat bukan pajak, sehingga tujuan yang diidamkan lebih gampang tercapai.

\section{- Kinerja}

(Lijan Poltak Sinambela, 2019) menyatakan, sangatlah sulit untuk menerapkan suatu definisi kinerja yang dapat memberikan pengertian yang komperhensif. Penggunaan kata kinerja sendiripun kadang-kadang disamaartikan dengan efektivitas pengelolaan, efektifvitas kerja, hasil kerja, pencapaian tujuan, produktivitas kerja, dan berbagai istilah lainnya. Sekalipun ada persamaan pengertian kinerja dengan berbagai istilah tersebut, akan tetap terdapat perbedaan pengertian dasarnya maupun prosesnya. Dari uraian ini, bisa dinyatakan bahwa yang relevan dengan kinerja antara lain adalah: (1) memasukkan, (2) memenuhi atau menjalankan sesuatu (3) melaksanakan tangggung jawab dan (4) melakukan sesuatu yang diharapkan oleh seseorang. Dengan demikian, Kinerja dapat diartikan sebagai pelaksanaan suatu pekerjaaan dan penyempurnaan pekerjaan tersebut sesuai dengan tanggung jawabnya sehingga dapat dicapai hasil dengan yang diharapkan.

(Prawirosentono, 1999) mendefinisikan kinerja sebagai hasil kerja yang dapat dicapai oleh seseorang atau sekelompok orang dalam suatu organisasi, sesuai dengan wewenang dan tanggung jawab masing-masing dalam rangka mencapai tujuan organisasi bersangkutan secara legal tidak melanggar hukum, sesuai moral dan etika. Pengertian ini merujuk pada kinerja sebagai tingkatan keberhasilan seseorang atau lembaga dalam melaksanakan pekerjaannya. Atau, setidaknya ada dua komponen pada kinerja, yaitu: (1) hasil kerja yang dicapai secara individu atau secara institusi, yang berarti bahwa kinerja tersebut adalah hasil akhir yang diperoleh secara sendiri-sendiri atau sekelompok, dan; (2) dalam melaksanakan tugas, orang atau lembaga diberikan wewenang dan tanggung jawab, yang berarti orang atau lembaga diberikan hak dan kekuasaan untuk bertindak sehingga pekerjaannya dapat dilakukan dengan baik.

Dalam mencapai tujuan organisasi yang telah ditetapkan, pimpinan melakukan tugas-tugasnya dibantu oleh pimpinan yang lainnya bersama dengan pegawai mereka. Keberhasilan pimpinan melaksanakan tugasnya akan dipengaruhi oleh kontribusi pihak lain. Artinya, kinerja pimpinan dipengaruhi oleh kinerja individu, jika kinerja individu baik akan mempengaruhi kinerja pimpinan dan kinerja organisasi. Untuk mengetahui kinerja organisasi perlu melakukan pengukuran. Adapun indikator kinerja organisasi, antara lain adalah efektivitas dan efesiensi (Rosenzweiq dalam Sinambela, 2012).

(Rivai dan Basri, 2005) mengemukakan bahwa kinerja adalah hasil atau tingkat keberhasilan seseorang atau keseluruhan selama periode tertentu di dalam melaksanakan tugas dibandingkan dengan berbagai kemungkinan, seperti standar hasil kerja, target atau sasaran atau kriteria yang telah ditentukan terlebih dahulu dan telah disepakati bersama. Dalam melakukan kinerja diperlukan strategi tentang manajemen kinerja adalah suatu proses pengelolaan (perencanaan, pengorganisasian penggerakan sampai pada pengawasan) pekerjaan, sehingga hasil pekerjaan tersebut dapat optimal. Menurut (Mohamad Mahsun, 2012), kinerja adalah gambaran 
mengenai tingkat pencapaian pelaksanaan suatu kegiatan/program/kebijakan dalam mewujudkan sasaran, tujuan, misi dan visi organisasi yang tertuang dalam strategi planning suatu organisasi.

\section{- Kinerja Keuangan}

Pengertian kinerja keuangan, oleh (Mulyadi, 2005) dinyatakan sebagai penentuan ukuran-ukuran tertentu yang dapat mengukur keberhasilan suatu perusahaan dalam menghasilkan laba. (Barlian, 2003) menyatakan bahwa Kinerja Keuangan merupakan prospek ataupun masa depan, perkembangan serta kemampuan pertumbuhan yang baik untuk industri. Sedangkan (Sucipto, 2007) mendefinisikan kinerja keuangan perusahaan sebagai hasil dari banyak keputusan individual yang dibuat secara terus menerus oleh manajemen.

Manajemen Kinerja adalah suatu proses manajerial mengenai perencanaan, evaluasi dan penilaian kinerja perangkat organisasi untuk mewujudkan tujuan organisasi. Melalui manajemen kinerja kita dapat mengetahui apakah pekerjaan yang dilakukan selama ini sudah berada pada jalur yang benar atau tidak. Dengan kata lain manajemen kinerja tidak hanya terkait kinerja pegawai secara individu, tetapi juga kinerja organisasi secara keseluruhan, sebagaimana dikemukakan oleh American Compensation Association (1996), bahwa suatu sistem manajemen kinerja yang efektif sejalan dengan kinerja individu dengan misi organisasi, visi dan tujuan.

Dari pengertian di atas, bisa disebutkan bahwa kinerja keuangan merupakan pekerjaan yang dilakukan setiap organisasi untuk mengukur dan menilai setiap keberhasilan yang dicapai dalam menghasilkan keuntungan, sehingga organisasi dapat melihat prospek, pertumbuhan, dan potensi perkembangan yang telah dicapai oleh organisasi tersebut. Suatu organisasi dapat dikatakan berhasil apabila telah mencapai standar dan tujuan yang telah ditetapkan. Dengan demikian, bisa pula dinyatakan bahwa data kinerja keuangan dibutuhkan untuk memperhitungkan pergantian sumber energi ekonomi potensial, yang bisa dikendalikan di masa depan serta untuk memprediksi kapasitas penciptaan sumber energi tersebut.

(Munawir, 2012) menyebutkan bahwa tujuan kinerja keuangan adalah sebagai berikut:

a) Mengetahui tingkat likuiditas, dimana likuiditas menunjukkan kemampuan perusahaan dalam memenuhi kewajiban keuangan yang wajib dituntaskan saat waktunya ditagih.

b) Mengenali tingkat solvabilitas, dimana solvabilitas menunjukkan kemampuan industri untuk memenuhi kewajiban keuangannya apabila industri tersebut dilikuidasi, baik keuangan jangka pendek maupun jangka panjang.

c) Mengenali tingkat rentabilitas atau profitabilitas yang menunjukkan kemampuan industri untuk mendapatkan laba sepanjang periode tertentu, dan

d) Mengenali tingkat stabilitas untuk menunjukkan kemampuan industri dalam melakukan usaha secara normal yang diukur melalui kemampuan industri dalam membayar hutangnya dan membayar beban bunga atas hutang pada waktunya. 
- Pengukuran dan Penilaian Kinerja Keuangan

Pengukuran serta penilaian atau evaluasi kinerja keuangan sangat berhubungan erat. Pengukuran kinerja ialah kualifikasi serta efisiensi dan daya guna industri dalam pengoperasian bisnis sepanjang periode akuntansi. Menurut (Srimindarti, 2006), evaluasi kinerja ialah ketentuan akan kekuatan operasional oleh organisasi, serta pegawai/karyawan yang berasal pada sasaran, ketentuan serta spesifikasi yang sudah ditetapkan sebelumnya secara berkala. Pengukuran kinerja diaplikasikan oleh industri untuk melakukan revisi atas aktivitas operasionalnya agar dapat memacu kinerja di dunia luar. Sedangkan analisis kinerja keuangan ialah proses mengevaluasi tentang efektivitas dalam pertanggungjawaban keuangan secara transparan dan akuntabel berdasarkan asas peraturan yang berlaku.

(Mathis dan Jackson, 2006) berpendapat bahwa penilaian kerja ialah proses evaluasi terhadap karyawan dalam melakukan pekerjaan yang dikomparasikan dengan standar yang dilanjutkan dengan memberi informasi tersebut kepada karyawan. Pengertian ini dapat juga diartikan bahwa penilaian kinerja merupakan pemberian peringkat pada karyawan melalui peninjauan, evaluasi dan penilaian hasil kerja.

Dengan demikian, pengukuran kinerja yang mengunakan alat ukur yang tidak obyektif, akan menghasilkan data yang tidak dapat menunjukan hasil yang sesungguhnya, sehingga bisa menimbulkan ketidakpercayaan hasil pengukuran di tingkat pegawai maupun di tingkat pimpinan organisasi. Metode pengukuran kinerja menjadi penting, mengingat bagus tidaknya penilaian kinerja akan dipengaruhi oleh tepat tidaknya metode penilaian yang dipilih dan diimplementasikan. Dalam mengukur kinerja keuangan, perlu dilihat bentuk organisasinya. Dalam melihat organisasi perusahaan, ukuran kinerja keuangan dapat diketahui melalui besarnya tanggungjawab manajer yang diwujudkan dalam bentuk prestasi kinerja keuangan.

Sedangkan dalam melakukan pengukuran kinerja keuangan pemerintah, baik pusat maupun daerah, harus dilihat secara ekonomis, efisien dan efektif atau memenuhi value for money serta transparansi, akuntabilitas, keadilan dan partisipasi masyarakat agar bisa mendorong pertumbuhan perekomian yang diharapkan bisa mengurangi jumlah penganggaran serta menurunkan angka kemiskinan. Karena itu, kebutuhan pengukuran kinerja keuangan penyelenggara negara bisa dilihat dari seberapa jauh kinerja yang telah dihasilkan dalam suatu periode tertentu dibandingkan dengan yang telah direncanakan.

\section{- Penelitian Terdahulu}

Beberapa penelitian empiris tentang pengaruh efektivitas pengelolaan PNBP terhadap kinerja keuangan, pada pokoknya membuktikan bahwa faktor yang mempengaruhi adalah berbeda-beda. Hal ini bisa terjadi karena adanya perbedaan tempat kerja, perbedaan data yang digunakan, perbedaan periode pengamatan dan lain sebagainya. Begitu pula dengan penelitian efektivitas pengelolaan PNBP, memberikan hasil yang beragam. Ada yang menyatakan efektivitas pengelolaan PNBP berpengaruh positif, dan ada yang menyebutkan berpengaruh negatif.

Studi yang dilakukan (Angraini, et al, 2018) menyebutkan bahwa Pengelolaan PNBP pada Satuan Kerja Kantor Pertanahan Kabupaten Parigi 
Mountong masih belum optimal pada tahap perencanaan dan penganggaran, pelaksanaan, penatausahaan, pengawasan dan pelaporan serta pertanggungjawaban. Sedangkan tingkat pertumbuhan target PNBP (2011-2015) cenderung meningkat, namun pertumbuhan berfluktuasi setiap tahunnya, tergantung jumlah permohonan masyarakat yang mengajukan layanan pertanahan. Sementara, efektivitas pengelolaan PNBP (2011-2015) masih belum efektif, disebabkan realisasi penerimaan tidak mencapai target.

Penelitian yang dilakukan (Nursanti et al, 2019) menunjukkan hasil yang menyebutkan bahwa pengelolaan Penerimaan Negara Bukan Pajak pada Kantor Pertanahan Kota Makassar secara keseluruhan termasuk dalam kategori efektif, meskipun dalam beberapa kegiatan pelayanan pertanahan masih diperlukan perbaikan dalam segala aspek, baik itu dari sistem pelayanan, sarana dan prasarana, sumber daya manusia yang memadai, perencanaan anggaran, pelaksanaan dan pengawasan. Pengelolaan PNBP sudah sesuai dengan SPOPP yang berlaku pada Kementerian ATR/BPN berdasarkan Peraturan Kepala BPN RI Nomor 1 Tahun 2010. Dari jenis pelayanan, tarif yang ditentukan, jangka waktu penyelesaian dan persyaratan yang ditetapkan. Meskipun masih perlu dilakukan inovasi pelayanan untuk percepatan kegiatan pelayanan pertanahan.

(Hastuti, 2018) menyebutkan bahwa Peraturan Pemerintah Nomor 12 Tahun 2014 serta peraturan pelaksanaan lainnya yang berperan melengkapi Peraturan Pemerintah tersebut menjadi dasar hukum bagi penetapan tarif agar sesuai dengan yang telah ditetapkan, kepatuhan pengelolaan dan penyetoran PNBP ke kas negara, yang kemudian jumlah penerimaannya menggambarkan keefektifan kebijakan PNBP ke kas negara melalui perbandingan antara realisasi penerimaan dan target penerimaan.

Hasil penelitian (Sasmito dan Anton Wahidin Widjaja, 2018) menyebutkan bahwa Penerimaan Kekayaan Intelektual berpengaruh signifikan paling dominan terhadap PNBP. Koefisien Penerimaan Kekayaan Intelektual sebesar 7,531, yang bisa diartikan bahwa setiap peningkatan Penerimaan Kekayaan Intelektual sebesar $1 \%$ maka akan mengakibatkan kenaikan PNBP entitas sebesar 7,531\%. Sedangkan koefisien Penerimaan Administrasi Hukum umumnya sebesar 1,317, yang berarti jika setiap peningkatan Penerimaan Administrasi Hukum sebesar 1\% maka akan mengakibatkan kenaikan PNBP entitas sebesar1,317\%. Dan, yang paling kecil berdasarkan hasil SPSS yaitu Penerimaan Keimigrasian yang menunjukkan bahwa setiap peningkatan penerimaan Keimigrasian sebesar $1 \%$ maka akan mengakibatkan kenaikan PNBP entitas sebesar 0,369\%. Berdasarkan hasil pengujian uji f, variablevariabel penerimaan Kekayaan Intelektual, Penerimaan Administrasi Hukum Umum dan Penerimaan Keimigrasian secara bersama-sama berpengaruh signifikan terhadap PNBP pada Kementerian Hukum dan HAM RI, karena nilai signifikannya sebesar 0,001 lebih kecil dari 0,05.

(Hilda Mataris et al, 2019) menyebutkan bahwa kinerja keuangan daerah Kabupaten Magelang dilihat dari RDDF sebesar 17,25\% masuk kriteria kurang dalam meningkatkan PAD-nya. Pada Derajat Efektivitas, PAD sebesar 110,29\% dengan kriteria sangat efektif, telah baik dan mampu dalam pengelolaan PAD. Dari sisi REKD adalah sebesar $655,42 \%$ dengan kriteria tidak efektif, yakni jumlah 
angka Belanja Daerah lebih besar dari realisasi PAD. Keserasian Belanja Operasional berada di angka 39,17\% berada kurang dari separuhnya dari seluruh Total Belanja Daerah atau kurang dari 50\%. Keserasian Belanja Modal adalah sebesar $18,45 \%$ yang mencerminkan besarnya alokasi belanja daerah untuk belanja modal masih serasi berada di bawah angka 20\%. Pemerintah Kab. Magelang masih memprioritaskan Belanja Operasional jangka pendek tahunan dari APBD-nya dibandingkan dengan Belanja Modal untuk pembangunan jangka panjang.

Berdasarkan hasil penelitian terdahulu, maka penelitian ini dilakukan untuk menguji pengaruh efektivitas pengelolaan PNBP terhadap kinerja keuangan di Badan Pengembangan dan Pembinaan Bahasa berdasarkan data Laporan Realisasi Anggaran Pendapatan pada Badan Pengembangan dan Pembinaan Bahasa pada tahun 2018, 2019 dan per Juni 2020, yang mana data tersebut menunjukan adanya tingkat kenaikan serta penurunan pendapatan PNBP.

\section{Kerangka Pemikiran}

Kerangka pemikiran merupakan uraian tentang hubungan antara variabel yang terkait dengan masalah yang diteliti sesuai dengan rumusan masalah. Pada penelitian ini, secara skematis kerangka pemikiran digambarkan sebagaimana Gambar 1.

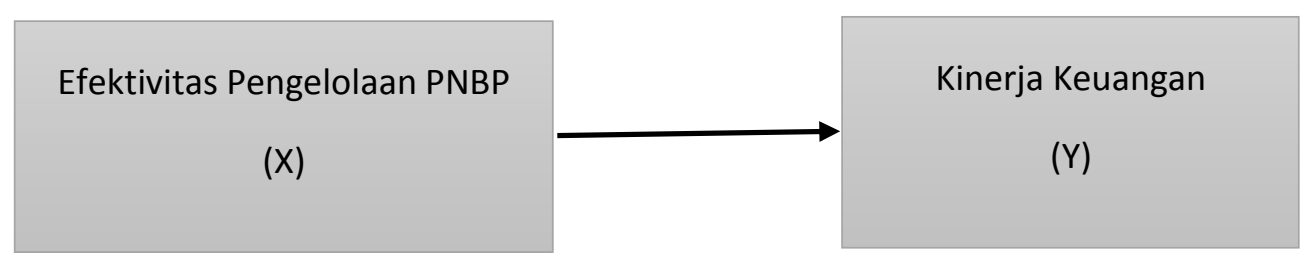

Gambar 1. Kerangka Pemikiran

\section{Hipotesis Penelitian}

Hipotesis adalah jawaban sementara terhadap rumusan masalah penelitian, dimana rumusan masalah telah dinyatakan dalam bentuk kalimat pertanyaan. Selanjutnya hipotesis akan diuji oleh peneliti dengan menggunakan pendekatan kuantitatif (Sugiyono, 2015). Dengan ketentuan tersebut, maka hipotesis yang dirumuskan pada penelitian ini adalah sebagai berikut:

- Hipotesa Nol (Ho): Efektivitas pengelolaan PNBP berpengaruh negatif dan signifikan terhadap kinerja keuangan.

- Hipotesa Alternatif (Ha): Efektivitas pengelolaan PNBP berpengaruh positif terhadap kinerja keuangan, berpengaruh positif dan signifikan terhadap kinerja keuangan.

\section{METODE}

Penelitian ini merupakan jenis penelitian kuantitatif, yaitu penelitian empiris yang datanya berbentuk angka-angka (Syahrum \& Salim, 2010). Penelitian kuantitatif juga merupakan jenis penelitian yang menghasilkan penemuan-penemuan 
yang dapat dicapai dengan menggunakan prosedur-prosedur statistik atau cara-cara lain dari kuantifikasi atau pengukuran (Sugiyono, 2015).

Metode kuantitatif adalah metodologi penelitian yang berlandaskan pada filsafat positivisme, yang digunakan untuk meneliti pada populasi atau sampel tertentu dan untuk menguji hipotesis yang telah ditetapkan. Jenis penelitian yang digunakan dalam penelitian ini menggunakan jenis penelitian survei. Dalam penelitian surveI, informasi yang dikumpulkan dari responden dengan menggunakan kuesioner (Sugiyono, 2015).

Model penelitian yang diterapkan dalam penelitian ini termasuk model penelitian asosiatif. Penelitian asosiatif adalah penelitian yang dilakukan untuk mencari hubungan satu atau lebih variabel independen atau bebas (X) terhadap variabel dependen atau terikat (Y) (Suryani \& Hendryadi, 2015). Penelitian ini mencari hubungan atau pengaruh sebab-akibat, antara variabel independen (X), yaitu Efektivitas Pengelolaan PNBP terhadap variabel dependen (Y), yaitu Kinerja Keuangan di Badan Pengembangan dan Pembinaan Bahasa.

Penelitian ini dilakukan pada Bulan Januari 2021 di Badan Pengembangan dan Pembinaan Bahasa, Kementerian Pendidikan dan Kebudayaan yang terletak di Jalan Daksinapati Barat IV, Rawamangun, Jakarta Timur.

\section{- Definisi Konseptual}

Penelitian ini dilakukan dengan menggunakan dua konsep, yaitu efektivitas pengelolaan PNBP dan kinerja keuangan. Efektivitas pengelolaan PNBP merupakan salah satu faktor yang menunjang dalam rangka pengelolaan keuangan. Sedangkan PNBP dirumuskan sebagaimana disebutkan pada UU Nomor 9 Tahun 2018: “...pungutan yang dibayar oleh orang pribadi atau badan dengan memperoleh manfaat langsung maupun tidak langsung atas layanan atau pemanfaatan sumber daya dan hak yang diperoleh negara, berdasarkan peraturan perundang-undangan, yang menjadi penerimaan pemerintah pusat di luar penerimaan perpajakan dan hibah dan dikelola dalam mekanisme anggaran pendapatan dan belanja negara.

Dengan demikian, dapat diambil kesimpulan bahwa efektivitas pengelolaan PNBP merupakan hasil pemungutan yang dibayar oleh pribadi maupun masyarakat baik yang diperoleh secara langsung maupun tidak langsung berdasarkan peraturan perundang-undangan dalam rangka penatausahaan kinerja keuangan , sesuai dengan peraturan dan norma yang berlaku.

\section{- Definisi Operasional}

Definisi operasional merupakan proses pemindahan dari definisi konseptual suatu konstruk kepada aktivitas atau pengukur tertentu yang memungkinkan peneliti mengamatinya secara empiris. Adapun pengukur tertentu yang dimaksud adalah:

$\mathrm{Y}=$ Efektivitas pengelolaan PNBP, variabel ini diukur dengan skala Likert.

$\mathrm{X} 1$ = Kinerja Keuangan, variabel ini diukur dengan skala Likert

\section{- Populasi Dan Sampel}

Populasi merupakan keseluruhan kelompok orang, kejadian atau hal minat yang ingin peneliti investigasi. Populasi adalah wilayah generalisasi yang terdiri dari 
objek atau subjek penelitian yang mempunyai kualitas dan karakteristik tertentu yang ditentukan peneliti, dipelajari dan ditarik kesimpulannya (Sugiyono, 2015). Adapun jumlah populasi dalam penelitian ini adalah 40 pegawai.

Sampel adalah sebagian dari jumlah karakteristik yang dimiliki oleh populasi tersebut. Sampel dan populasi menjadi sumber data yang sebenarnya dalam suatu penelitian. Dengan kata lain sampel adalah bagian dari populasi, untuk mewakili populasi dalam arti sampel harus bersifat representatif. Jika jumlah populasi kurang dari 100 orang, maka jumlah sampel diambil secara keseluruhan, tetapi jika populasinya lebih besar dari 100 orang, maka bisa diambil antara 10-25\% atau $25-30 \%$ atau lebih tergantung dari kemampuan peneliti dilihat dari segi waktu, tenaga dan dana seperti sempit luasnya wilayah dan besar kecilnya resiko yang di tanggung oleh peneliti (Sugiyono, 2015). Oleh karena jumlah populasi pada penelitian ini lebih kecil dari 100 orang maka penulis mengambil sampel sebanyak 40 orang.

\section{- Instrumen Penelitian}

Pada penelitian ini instrumen yang digunakan untuk mengumpulkan data adalah kuesioner. Kuisioner merupakan teknik pengumpulan data yang dilakukan dengan cara memberikan separangkat pertanyaan tertulis pada responden untuk dijawabnya. Responden adalah orang yang akan diteliti (sampel). Kuisioner yang berupa pertanyaan disebarkan kepada responden sesuai dengan permasalahan yang diteliti. Kuisioner merupakan tekhnik pengumpulan data yang efisien bila peneliti tahu dengan pasti variabel yang akan diukur dan tahu apa yang bisa diharapkan dari responden (Sugiyono, 2015).

\section{Uji Hipotesis}

Pengujian hipotesis yang dilakukan pada penelitian ini meliputi:

- Uji Determinasi $\left(\mathrm{R}^{2}\right)$

Pengujian ini dilakukan untuk mengetahui berapa besar persentase pengaruh antara variabel bebas terhadap variabel terikat. Jika $\left(\mathrm{R}^{2}\right)$ semakin besar (mendekati satu), maka dapat dikatakan bahwa kemampuan mempengaruhi variabel bebas adalah besar terhadap variabel terikat. Hal ini berarti model yang digunakan semakin kuat untuk menerangkan pengaruh variabel bebas terhadap variabel terikat. Sebaliknya, jika $\left(\mathrm{R}^{2}\right)$ semakin kecil (mendekati nol) maka dapat dikatakan bahwa pengaruh variabel bebas terhadap variabel terikat semakin kecil. Hal ini berarti model yang digunakan tidak kuat untuk menerangkan pengaruh variabel bebas yangditeliti terhadap variabel terikat. Rumus untuk Uji Determinasi adalah sebagai berikut:

$$
\mathrm{dt}=\mathrm{r}^{2} \times 100 \%
$$

\section{- Uji Parsial (Uji T)}

Uji t digunakan untuk mengetahui apakah variabel-variabel independen secara parsial berpengaruh nyata atau tidak terhadap variabel dependen. Derajat 
signifikasi yang digunakan adalah 0,05 . Apabila nilai signifikan lebih kecil dari derajat kepercayaan kita maka hipotesis alternatif, yang menyatakan bahwa suatu variabel independen secara parsial mempengaruhi variabel dependen (Suryani \& Hendryadi, 2015). Berdasarkan perbandingan nilai thitung dengan tabel maka disimpulkan:

1. Jika nilai thitung > tabel maka variabel bebas berpengaruh terhadap variabel terikat.

2. Jika nilai thitung < tabel maka variabel bebas tidak berpengaruh terhadap variabel terikat.

\section{Analisis Data}

Untuk mendukung hasil penelitian, data penelitian yang diperoleh akan di analisis dengan metode regresi sederhana dan di olah dengan bantuan SPSS ver. 23. Adapun uji yang akan dilakukan dalam penelitian ini adalah:

\section{- Metode Skala Likert}

Skala Likert adalah skala yang dapat digunakan untuk mengukur sikap, pendapat dan persepsi seseorang tentang suatu objek atau fenomena tertentu. Skala Likert memiliki dua bentuk pernyataan, yaitu pernyataan positif dan negatif. Pernyataan positif diberi skor 5, 4, 3, 2, dan 1, sedangkan pernyataan negatif diberi skor 1, 2, 3, 4, dan 5. Bentuk pernyataan terdiri dari sangat setuju, setuju, kurang setuju, tidak setuju dan sangat tidak setuju (Sugiyono, 2015).

Peneliti memberikan 5 (lima) alternatif jawaban kepada responden, maka skala yang digunakan 1 sampai 5 , dengan bobot pemetaan adalah sebagai berikut:

$\begin{array}{ll}\text { Sangat Setuju } & =5 \\ \text { Setuju } & =4 \\ \text { Ragu-ragu } & =3 \\ \text { Tidak Setuju } & =2 \\ \text { Sangat Tidak Setuju } & =1\end{array}$

\section{Uji Kualitas Data}

\section{- Uji Validitas}

Validitas adalah suatu ukuran yang menunjukkan tingkat-tingkat kevalidan atau kesahihan suatu instrumen. Suatu instrumen yang valid atau sahih mempunyai validitas tinggi. Sebaliknya, instrumen yang kurang valid berarti memiliki validitas rendah. Uji validitas instrumen dilakukan dengan menggunakan program SPSS, untuk mengetahui instrumen penelitian mampu mencerminkan isi sesuai hal dan sifat yang diukur, artinya, setiap butir instrumen telah benar-benar menggambarkan keseluruhan isi atau sifat bangun konsep yang menjadi dasar penyusunan instrument (Ghozali, 2005). Untuk pengujian ini digunakan korelasi antar skor butir pertanyaan dengan total skor konstruk atau variabel. Kriteria dalam pengujian ini jika:

1. $\quad$ hitung $>{ }^{\mathrm{r}}$ tabel maka pertanyaan valid

2. $\quad$ hitung $<{ }^{\mathrm{r}}$ tabel maka pertanyaan tidak valid 
- Uji Realibilitas

Uji reliabilitas adalah alat untuk mengukur suatu kuesioner yang mempunyai indikator dari variabel atau konstruk. Suatu kuisioner dinyatakan reliabel atau handal jika jawaban seseorang terhadap pernyataan adalah konsisten atau stabil dari waktu ke waktu. Uji reliabilitas dapat dilakukan dengan menggunakan bantuan program SPSS, yang akan memberikan fasilitas untuk mengukur reliabilitas dengan uji statistik Cronbach Alpha $(\alpha)$. Suatu konstruk atau variabel dikatakan reliabel jika memberikan nilai Cronbanch Alpha > 0,60 (Ghozali, 2005).

- Uji Regresi Sederhana

Analisis data adalah proses penyederhanaan data ke dalam bentuk yang lebih mudah dibaca atau interpretasikan. Teknik analisis data yang digunakan pada penelitian ini yaitu teknik analisis regresi sederhana. Regresi sederhana adalah untuk sebuah variabel dependen dan satu buah variabel independent (Ghozali, 2005). Rumus untuk regresi sederhana adalah:

$$
\mathrm{Y}=\alpha+\mathrm{bX}+\varepsilon
$$

Dimana:

$\mathrm{Y}=$ Variabel Dependen (Efektivitas Pengelolaan PNBP)

$\mathrm{X}=$ Variabel Independen (Kinerja Keuangan)

$\alpha=$ Konstanta

$\mathrm{b}=$ koefisien regresi

\section{HASIL}

Pengujian yang dilakukan untuk mengetahui apakah instrumen penelitian dapat digunakan sebagai alat untuk mengumpulkan data yang dibutuhkan dalam pelaksanaan penelitian, diperoleh hasil sebagai berikut:

\section{Uji Validitas}

- Variabel Efektivitas Pengelolaan PNBP

Tabel 1. Uji Validitas Kuesioner Variabel Efektivitas Pengelolaan PNBP

\begin{tabular}{|c|c|c|c|}
\hline Kuesioner & $\mathrm{r}_{\text {hitung }}$ & $\mathrm{r}_{\text {tabel }}$ & Validitas \\
\hline 1 & 0.580 & 0.2638 & Valid \\
\hline 2 & 0.545 & 0.2638 & Valid \\
\hline 3 & 0.720 & 0.2638 & Valid \\
\hline 4 & 0.756 & 0.2638 & Valid \\
\hline 5 & 0.700 & 0.2638 & Valid \\
\hline 6 & 0.628 & 0.2638 & Valid \\
\hline 7 & 0.690 & 0.2638 & Valid \\
\hline
\end{tabular}




\begin{tabular}{|c|c|c|c|}
\hline 8 & 0.724 & 0.2638 & Valid \\
\hline 9 & 0.732 & 0.2638 & Valid \\
\hline 10 & 0.759 & 0.2638 & Valid \\
\hline 11 & 0.784 & 0.2638 & Valid \\
\hline 12 & 0.605 & 0.2638 & Valid \\
\hline 13 & 0.530 & 0.2638 & Valid \\
\hline 14 & 0.671 & 0.2638 & Valid \\
\hline 15 & 0.477 & 0.2638 & Valid \\
\hline
\end{tabular}

Sumber: Data Peneliti (2021).

Pada Tabel 1, nilai $r_{\text {tabel }}$ uji dua sisi pada taraf kepercayaan 95\% atau signifikan 5\% $(\mathrm{p}=0,05)$ dicari berdasarkan jumlah responden atau $\mathrm{N}$. Oleh karena $\mathrm{N}$ $=40$ maka derajat bebasnya $(\mathrm{df})$ adalah $\mathrm{N}-2(40-2=38)$. Nilai $\mathrm{r}_{\text {tabel }}$ di sisi $\mathrm{df}=38$ dan $p=0,05$ adalah 0,2638 . Butir pernyataan dinyatakan valid jika nilai $r_{\text {hitung }}>r_{\text {tabel }}$. Hasil output pada Tabel 1 menunjukkan bahwa 15 pertanyaan variabel efektivitas pengelolaan PNBP yang diajukan kepada responden dinyatakan valid.

- Variabel Kinerja keuangan

Tabel 2. Uji Validitas Variabel Kinerja Keuangan

\begin{tabular}{|c|c|c|c|}
\hline Kuesioner & $\mathbf{r}_{\text {hitung }}$ & $\mathbf{r}_{\text {tabel }}$ & Validitas \\
\hline 1 & 0.694 & 0.2638 & Valid \\
\hline 2 & 0.797 & 0.2638 & Valid \\
\hline 3 & 0.746 & 0.2638 & Valid \\
\hline 4 & 0.776 & 0.2638 & Valid \\
\hline 5 & 0.880 & 0.2638 & Valid \\
\hline 6 & 0.790 & 0.2638 & Valid \\
\hline 7 & 0.810 & 0.2638 & Valid \\
\hline 8 & 0.830 & 0.2638 & Valid \\
\hline 9 & 0.877 & 0.2638 & Valid \\
\hline 10 & 0.774 & 0.2638 & Valid \\
\hline 11 & 0.828 & 0.2638 & Valid \\
\hline 12 & 0.887 & 0.2638 & Valid \\
\hline 13 & 0.788 & 0.2638 & Valid \\
\hline 14 & 0.851 & 0.2638 & Valid \\
\hline 15 & 0.741 & 0.2638 & Valid \\
\hline
\end{tabular}

Sumber: Data Peneliti (2021).

Nilai $r_{\text {tabe }} l$ untuk uji dua sisi pada taraf kepercayaan $95 \%$ atau signifikan $5 \%$ $(\mathrm{p}=0,05)$ dapat dicari berdasarkan jumlah responden atau $\mathrm{N}$. Oleh karena $\mathrm{N}=40$ maka derajat bebasnya $(\mathrm{df})$ adalah $\mathrm{N}-2(40-2=38)$. Nilai $\mathrm{r}_{\text {tabel }}$ satu sisi pada $\mathrm{df}=38$ dan $\mathrm{p}=0,05$ adalah 0,2638. Butir pernyataan dinyatakan valid jika nilai $r_{\text {hitung }}>r_{\text {tabel }}$. 
Dari hasil output pada Tabel 2 menunjukkan bahwa 15 pertanyaan variabel kinerja keuangan yang diajukan kepada responden dinyatakan valid.

- Uji Reliabilitas

Uji reliabilitas dilakukan dengan internal consistency. Hasil uji ini akan mencerminkan dapat dipercaya atau tidaknya suatu instrumen penelitian, berdasarkan pada tingkat ketepatan dan kemantapan suatu alat ukur. Adapun tingkat reliabilitas dengan Alpha Cronbach diukur dari skala 0-1 (Ghozali, 2005).

Tabel 3. Tingkat Reliabilitas Berdasarkan Nilai Alpha

\begin{tabular}{|c|c|}
\hline Alpha & Tingkat Reliabilitas \\
\hline $0.00-0.20$ & Kurang \\
\hline $0.20-0.40$ & Agak Reliabel \\
\hline $0.40-0.60$ & Cukup Reliabel \\
\hline $0.60-0.80$ & Reliabel \\
\hline $0.80-1.00$ & Sangat Reliabel \\
\hline
\end{tabular}

Tabel 4. Reliability Statistics

\begin{tabular}{|l|l|}
\hline Cronbach's Alpha & N of Items \\
\hline \hline, 860 & 15 \\
\hline
\end{tabular}

Sumber: Data Peneliti (2021)

Dari hasil uji reliabilitias pada Tabel 4 diketahui bahwa instrumen penelitian untuk variabel kinerja keuangan masuk dalam tingkatan Sangat Reliabel (dapat dipercaya) dengan nilai 0.860 .

Tabel 5. Reliability Statistics

\begin{tabular}{|l||l||}
\hline Cronbach's Alpha & N of Items \\
\hline \hline, 961 & 15 \\
\hline
\end{tabular}

Sumber: Analisis Peneliti (2021).

Instrumen untuk variabel kinerja keuangan pada Tabel 5 menunjukkan nilai 0.961 pada pengujian yang dilakukan. Dengan demikian instrument untuk variabel kinerja keuangan juga dinyatakan Sangat Reliabel. 


\section{Deskripsi Data}

Analisis deskriptif adalah analisis yang memberikan deskripsi suatu data yang dilihat dari nilai rata-rata (mean), standar deviasi, varian maksimum, minimum (Ghozali, 2005).

Tabel 6. Descriptive Statistics Variabel Efektifitas Pengelolaan PNBP

\begin{tabular}{|l|l|l|l|}
\hline \multicolumn{4}{|l|}{ Tabel Descriptive Statistics } \\
\hline & Maen & Std. Deviation & N \\
\hline D1 & 4.35 & .736 & 40 \\
\hline D2 & 3.78 & .832 & 40 \\
\hline D3 & 4.03 & 1.209 & 40 \\
\hline D4 & 4.33 & .694 & 40 \\
\hline D5 & 4.35 & .622 & 40 \\
\hline D6 & 4.08 & .572 & 40 \\
\hline D7 & 4.40 & .496 & 40 \\
\hline D8 & 4.43 & .549 & 40 \\
\hline D9 & 4.38 & .490 & 40 \\
\hline D10 & 4.35 & .580 & 40 \\
\hline D11 & 4.35 & .533 & 40 \\
\hline D12 & 4.10 & .496 & 40 \\
\hline D13 & 4.05 & .677 & 40 \\
\hline D14 & 2.73 & .905 & 40 \\
\hline D15 & 4.25 & .543 & 40 \\
\hline TotalX & 61.93 & 6.010 & 40 \\
\hline
\end{tabular}

Sumber: Data Peneliti (2021).

Hasil analisis deskriptif untuk variabel efektivitas pengelolaan PNBP menghasilkan nilai total rata-rata sebesar 61.93 dengan standar deviasi 6.010. Jika dilihat dari Tabel 6, maka dapat diketahui bahwa terdapat 13 item soal yang nilai reratanya adalah 4, yang artinya banyak responden menjawab setuju. Sementara nilai standar deviasi yang berada di atas 0 mengartikan bahwa data yang dihasilkan memiliki nilai di atas rata-rata.

Tabel 7. Descriptive Statistics Variabel Kinerja Keuangan

\begin{tabular}{|l|l|l|l|}
\hline \multicolumn{4}{|l|}{ Tabel Descriptive Statistics } \\
\hline & Mean & Std. Deviation & N \\
\hline P1 & 3.80 & .687 & 40 \\
\hline P2 & 3.85 & .622 & 40 \\
\hline P3 & 3.75 & .630 & 40 \\
\hline P4 & 3.40 & .841 & 40 \\
\hline P5 & 3.75 & .742 & 40 \\
\hline P6 & 3.78 & .660 & 40 \\
\hline P7 & 3.68 & .694 & 40 \\
\hline
\end{tabular}




\begin{tabular}{|l|l|l|l|}
\hline P8 & 3.80 & .723 & 40 \\
\hline P9 & 3.75 & .707 & 40 \\
\hline P10 & 3.68 & .656 & 40 \\
\hline P11 & 3.88 & .723 & 40 \\
\hline P12 & 3.63 & .774 & 40 \\
\hline P13 & 3.48 & .716 & 40 \\
\hline P14 & 3.78 & .698 & 40 \\
\hline P15 & 3.88 & .723 & 40 \\
\hline TotalY & 55.85 & 8.538 & 40 \\
\hline
\end{tabular}

Sumber: Data Peneliti (2021).

Untuk variabel Kinerja Keuangan pada Tabel 7, dihasilkan nilai rerata sebesar 55.85 yang artinya nilai tersebut masuk kategori sedang. Dengan nilai simpangan baku 8.538. sementara itu dari keseluruhan item soal kuesioner diketahui nilai rerata jawaban responden adalah 3 yang berarti ke 40 responden memberikan nilai setuju untuk setiap item pertanyaan kuesioner.

\section{Uji Korelasi}

Pengujian ini untuk mengetahui ada tidaknya hubungan antara variabel efektivitas pengelolaan PNBP dengan variabel kinerja keuangan di Badan Pengembangan dan Pembinaan Bahasa.

Tabel 8. Pearson Correlations

\begin{tabular}{|ll|l|l|}
\hline & & TotalX & TotalY \\
\hline TotalX & Pearson Correlation & 1 & .249 \\
& Sig. (2-tailed) & & .121 \\
& $\mathrm{~N}$ & 40 & 40 \\
\hline TotalY & Pearson Correlation & .249 & 1 \\
& Sig. (2-tailed) & .121 & \\
& $\mathrm{~N}$ & 40 & 40 \\
\hline
\end{tabular}

Sumber: Data Peneliti (2021).

Dari Tabel 8 dapat diketahui bahwa analisis uji Pearson Correlation menghasilkan nilai sebesar 0.249 ( > 0.05), sehingga dapat diartikan ada korelasi antara variabel efektivitas pengelolaan PNBP dengan variabel kinerja keuangan di Badan Pengembangan dan Pembinaan Bahasa.

\section{Analisis Regresi}

Analisis regresi linear sederhana digunakan untuk meramalkan hubungan secara linear antara variabel independen variabel independen. Dengan memperhitungkan variabel efektivitas pengelolaan PNBP diketahui berapa besar pengaruhnya terhadap kinerja keuangan di Badan Pengembangan dan Pembinaan 
Bahasa. Analisis regresi sederhana dalam penelitian ini menggunakan program SPSS (Statistic Product and Service Solution) versi 23. Tabel 9 adalah hasil uji regresi linear sederhana.

\section{Coefficients $^{\mathrm{a}}$}

Tabel 9. Hasil Regresi Linear

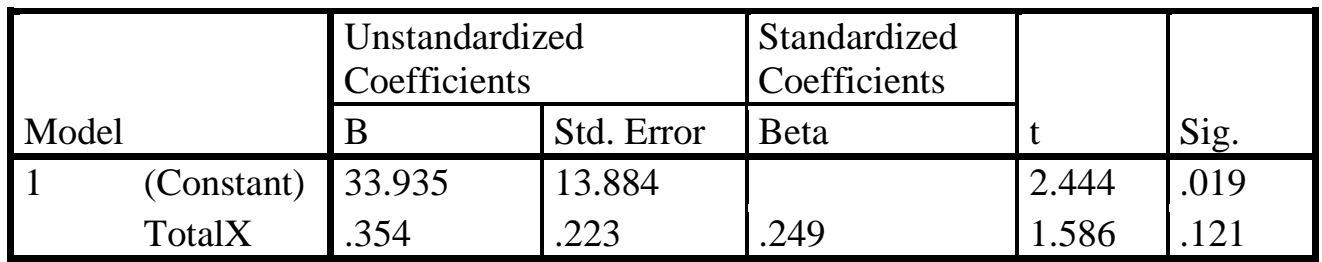

a. Dependent Variable: TotalY

Hasil regresi adalah:

$\mathrm{Y}=\alpha+b \mathrm{X}+\varepsilon$

$\mathrm{Y}=33.935+0.354 \mathrm{X}+\varepsilon$

Artinya:

- Nilai konstanta 10,695, menunjukkan bahwa jika variabel efektivitas pengelolaan $\mathrm{PNBP}(\mathrm{X})=0$, maka variabel kinerja keuangan $(\mathrm{Y})=33.935$

- Nilai koefisien 0,354 menunjukkan bahwa jika terjadi peningkatan efektivitas pengelolaan PNBP sebesar 1 satuan, maka akan mengakibatkan perubahan variabel kinerja keuangan meningkat sebesar 0,354

\section{Pengujian Hipotesis}

- Uji Determinasi $\left(\mathrm{R}^{2}\right)$

Uji ini digunakan untuk mengukur seberapa jauh kemampuan model dalam menerangkan variasi variabel independen. Nilainya adalah $0-1,0<R^{2}<1$ semakin mendekati nol berarti model tidak baik atau variasi model dalam menjelaskan sangat terbatas sebaliknya mendekati satu, maka suatu model akan semakin baik. Untuk mengetahui keeratan hubungan antara variabel efektivitas pengelolaan PNBP terhadap kinerja keuangan dapat dilihat dari nilai $\mathrm{R}^{2}$ tabel berikut:

Tabel 10. Model Summary $R^{2}$

\begin{tabular}{|l|l|l|l|l|}
\hline Model & $\mathrm{R}$ & R Square & $\begin{array}{l}\text { Adjusted } \\
\text { R Square }\end{array}$ & $\begin{array}{l}\text { Std. Error of } \\
\text { the Estimate }\end{array}$ \\
\hline 1 & $.249^{\mathrm{a}}$ & .062 & .037 & 8.377 \\
\hline
\end{tabular}

Sumber : Data Peneliti yang diolah oleh SPSS 23 (2021)

a. Predictors: (Constant), efektivitas pengelolaan PNBP

b. Dependent Variable: kinerja keuangan

Interpretasi dari Model Summary yaitu, nilai R Square sebesar 0.062 dimana model yang dibangun menunjukkan bahwa variabel efektivitas 
pengelolaan PNBP dengan kinerja keuangan saling berpengaruh sebesar 6.2\% dan sisanya dipengaruhi oleh faktor lain yang tidak diteliti dalam penelitian ini.

\section{Uji Parsial}

Untuk mengetahui secara parsial pengaruh efektivitas pengelolaan PNBP terhadap kinerja keuangan di Badan Pengembangan dan Pembinaan Bahasa, kreteria pengambilan keputusannya menurut Ghozali (2005), adalah:

Berdasarkan nilai $t_{\text {hitung }}>t_{\text {tabel }}$

- Jika nilai $t_{\text {hitung }}>t_{\text {tabel }}$ maka variabel bebas berpengaruh terhadap variabel terikat.

- Jika nilai $\mathrm{t}_{\text {hitung }}<\mathrm{t}_{\text {tabel }} \mathrm{l}$ maka variabel bebas tidak berpengaruh terhadap variabel terikat.

Berdasarkan nilai signifikansi hasil output SPSS

- Jika nilai sig < 0,05 maka variabel bebas berpengaruh signifikan terhadap variabel terikat.

- Jika nilai sig > 0,05 maka variabel bebas tidak berpengaruh signifikan terhadap variabel terikat.

Berdasarkan dari hasil output pada Tabel 9 diketahui bahwa nilai dari $\mathrm{t}_{\text {hitung }}$ variabel efektivitas pengelolaan PNBP adalah 2.444 dengan tingkat signifikansi 0,019 , sedangkan $t_{\text {tabel }}$ pada tingkat kepercayaan 95\% $(\alpha=0,05)$ adalah 2,048 sehingga $t_{\text {hitung }}>t_{\text {tabel }}(2.444<2,048)$ dan tingkat signifikansi $<0,05$ atau $(0,019<0,05)$ sehingga dapat dikatakan bahwa $\mathrm{H}_{0}$ diterima atau ada pengaruh antara efektivitas pengelolaan PNBP dengan kinerja keuangan Badan Pengembangan dan Pembinaan Bahasa.

\section{PEMBAHASAN}

Hasil analisis regresi linier (regresi sederhana) dan analisis korelasi sederhana (korelasi product moment) telah didapat angka-angka satistik yang dapat memberikan petunjuk atau gambaran tentang pengaruh variabel efektivitas pengelolaan PNBP (X) terhadap variabel kinerja keuangan (Y). Hasil analisis regresi linier untuk menguji pola hubungan pengaruh dari variabel efektivitas pengelolaan PNBP $(\mathrm{X})$ terhadap kinerja keuangan $(\mathrm{Y})$ didapat persamaan regresi $\mathrm{Y}$ $=33.935+0.354 \mathrm{X}+\varepsilon$. Pada Persamaan regresi tersebut, secara jelas koefisien arah regresi bertanda positif yaitu $b=+0,354$.

Ini mempunyai pengertian bahwa hubungan pengaruh variabel efektivitas pengelolaan PNBP terhadap kinerja keuangan ialah positif dengan pola perkembangan sebesar $1: 0.354$ yang artinya bahwa perkembangan/peningkatan efektivitas pengelolaan PNBP sebesar 1 skala akan menyebabkan perubahan/peningkatan kompetensi kinerja keuangan sebesar 0.354 skala. Dengan kata lain dapat diinterpretasikan bahwa apabila efektivitas pengelolaan PNBP bertambah sebesar 1 skala maka akan menyebabkan peningkatan kinerja keuangan sebesar 0.354 skala. Dapat diinterpretasikan apabila efektivitas pengelolaan PNBP meningkat $100 \%$ maka hal itu akan menyebabkan peningkatan kinerja keuangan sebesar $35.4 \%$. 
Selanjutnya, pada persamaan regresi didapat nilai koefisien konstanta adalah sebesar a $=33.935$; ini mempunyai makna jika efektivitas pengelolaan PNBP tidak bertambah atau bersifat konstan, maka kinerja keuangan hanya sebesar 33.935 skala, dan ini artinya bahwa tanpa efektivitas pengelolaan PNBP maka sulit mencapai kinerja keuangan yang tinggi.

Hasil analisis korelasi sederhana (product moment) juga membuktikan adanya pengaruh positif dan signifikan dari variabel efektivitas pengelolaan PNBP terhadap kinerja keuangan di Badan Pengembangan dan Pembinaan Bahasa, Kementerian Pendidikan dan Kebudayaan. Hasil analisis korelasi product moment diperoleh koefisien korelasi (r) sebesar 0,249 dan koefisien determinasi $\left(\mathrm{r}^{2}\right)$ sebesar 0.062 .

Nilai koefisien korelasi (r) mendekati angka maksimum koefisien korelasi $(1,000)$, sehingga dapat diinterpretasi bahwa derajat korelasi antara efektivitas pengelolaan PNBP dengan kinerja keuangan berada pada kategori tinggi/erat. Sedangkan nilai koefisien determinasi $\left(\mathrm{r}^{2}\right)$ sebesar 0,062 memberi petunjuk bahwa efektivitas pengelolaan PNBP mempunyai daya penentu/pengaruh sebesar $6.2 \%$ terhadap perkembangan atau naik-turunya kinerja keuangan di Badan Pengembangan dan Pembinaan Bahasa, Kementerian Pendidikan dan Kebudayaan.

Oleh karena koefisien koreasi dan determinasi bertanda $a$ positif, maka hal itu berarti bahwa pertambahan/peningkatan kinerja keuangan ditentukan/dipengaruhi oleh faktor efektivitas pengelolaan PNBP, sedangkan sisanya ditentukan/dipengaruhi oleh faktor-faktor lainnya. Derajat korelasi dan daya determinasi/pengaruh variabel efektivitas pengelolaan PNBP terhadap kinerja keuangan tersebut adalah nyata atau signifikan.

Keseluruhan hasil analisis statistik di atas, baik hasil analisis regresi linier maupun analisis korelasi product moment berserta seluruh pengujian signifikansinya (uji-t), menunjukkan bahwa efektivitas pengelolaan PNBP mempunyai mempunyai pengaruh positif dan signifikan terhadap kinerja keuangan di Badan Pengembangan dan Pembinaan Bahasa, Kementerian Pendidikan dan Kebudayaan. Dengan demikian dapat dinyatakan bahwa hipotesis yang diajukan dalam penelitian ini yakni "efektivitas pengelolaan PNBP berpengaruh positif dan signifikan terhadap kinerja keuangan”, dapat diterimasecara meyakinkan pada taraf signifikan 0,05 atau taraf kepercayaan/keyakinan $95 \%$.

Dengan diterima atau terujinya hipotesis penelitian tersebut, maka dengan demikian penelitian ini dapat membuktikan kebenaran kerangka teoritis yang telah dibangun sebagai landasan konseptual pada penelitian ini. Dengan demikian Ho ditolak dan $\mathrm{H}_{\mathrm{a}}$ diterima, maka sesuailah dengan apa yang dikemukakan (Rudianto, 2013) bahwa kinerja keuangan adalah hasil atau prestasi yang telah dicapai oleh manajemen perusahaan dalam menjalankan fungsinya mengelola aset perusahaan secara efektif selama periode tertentu. Kinerja keuangan sangat dibutuhkan oleh perusahaan untuk mengetahui dan mengevaluasi sampai dimana tingkat keberhasilan perusahaan berdasarkan aktivitas keuangan yang telah dilaksanakan. Hal yang dapat diperhatikan dalam pencapaian kinerja keuangan yang tinggi adalah mengenai efektivitas pengelolaan PNBP. 


\section{SIMPULAN DAN SARAN}

Efektivitas pengelolaan PNBP berpengaruh positif terhadap kinerja keuangan di Badan Pengembangan dan Pembinaan Bahasa, Kementerian Pendidikan dan Kebudayaan. Berdasarkan hasil analisis yang diperoleh dapat diketahui bahwa tingkat efektivitas pengelolaan PNBP yang baik dapat meningkatkan kemampuan kinerja keuangan pada tingkat yang lebih tinggi. Dapat dilihat pula bahwa dari sisi efektivitas pengelolaan PNBP juga termasuk memiliki kesadaran dan kesediaan untuk mentaati semua peraturan dan norma-norma sosial yang berlaku di organisasi.

Berdasarkan hasil koefesien determinasi diperoleh nilai sebesar 0,300 artinya efektivitas pengelolaan PNBP memiliki pengaruh terhadap kinerja keuangan sebesar $6.2 \%$, sedangkan sisanya dipengaruhi oleh variabel lain yang tidak dimasukan dalam variabel peneltian ini. Terdapat pengaruh positif dan signifikan antara variabel efektvitas pengelolaan PNBP terhadap kinerja keuangan di Badan Pengembangan dan Pembinaan Bahasa, hal ini ditunjukkan melalui hasil uji $t$ dimana nilai dari $\mathrm{t}$ hitung variabel efektivitas pengelolaan PNBP adalah 2.444 dengan tingkat signifikansi 0,019 , sedangkan tabel pada tingkat kepercayaan $95 \%(\alpha$ $=0,05)$ adalah 2,048 sehingga $t_{\text {hitung }}>t_{\text {tabel }}(2.444>2,048)$ yang berarti nilai tersebut signifikan.

Berdasarkan kesimpulan di atas, maka saran yang dapat diberikan dalam penelitian adalah: diharapkan Badan Pengembangan dan Pembinaan Bahasa bisa memperhatikan faktor lain guna meningkatkan PNBP, yang berpengaruh kuat terhadap efektivitas pengelolaan keuangan yang berupa Pendapatan Negara Bukan Pajak seperti teknologi informasi akuntasi, pengawasan fungsional dan lain-lain. Sehubungan dengan perihal tersebut perlu dilakukan sosialisasi tentang prosedur dan biaya pelayanan di Badan Pengembangan dan Pembinaan Bahasa yang harus dibayarkan oleh masyarakat sehingga tidak ada pungutan yang melebihi dari Standar Prosedur Operasional Pelayanan dan Pengaturan (SPOPP).

Dalam menambahkan variabel bebas yang diindikasikan mempengaruhi kinerja keuangan jika hendak melakukan penelitian serupa, maka pemerintah perlu melakukan revisi undang-undang atau regulasi terkait PNBP untuk penyempurnaan proses pengelolaan PNBP terutama mekanisme pemungutan, perhitungan, penyetoran dan sanksi dalam pengelolaan PNBP tersebut untuk mengoptimalkan kontribusi PNBP terhadap penerimaan negara. Dengan demikian diharapkan PNBP yang dibayarkan oleh para wajib bayar bisa lebih akurat, transparan dan akuntabel.

\section{DAFTAR PUSTAKA}

Adetya. (2014). Paper Penerimaan Negara.Program Diploma IV Akuntansi Kurikulum Khusus, STAN, Tangerang Selatan diakses pada tanggal 28 november 2014 dari http://www.academia.edu/7508148/

Paper_Penerimaan_Negara.

Angraini, Magfirah, Andi Mattulada Amir dan Nina Yusnita. (2018). Pengelolaan Penerimaan Negara Bukan Pajak Suatu Tinjauan Evaluatif (Studi pada 
Satuan Kerja Kantor Pertanahan Kabupaten Parigi Moutong), Jurnal Katalogis, Vol. 6/5, Mei 2018, hlm 23-34.

Buku Pedoman Akuntansi dan Penyusunan Laporan Keuangan berdasarkan Sistem Akutansi Pemerintah (SAP) di lingkungan Kementerian Pendidikan dan Kebudayaan tahun (2017). https://docplayerX.info/66699836-Pedomanakuntansi-dan-penyusunan-laporan-keuangan-berdasarkan-sap-dilingkungan-kemendikbud-kata-pengantar.html.

Buku Manajemen Kinerja Pengelolaan, Pengukuran dan Implementasi Kinerja, Prof. Lijan Poltak Sinambela, Dr. Sarton Sinambela, Cetakan ke 1, Januari (2019). Penerbit PT. Rajagrafindo Persada Depok.

Dinarjito, Agung. (2017). Pengelolaan Penerimaan Negara Bukan Pajak: Study Kasus pada Kantor Pertanahan Wilayah BPN Provinsi Daerah Istimewa Yogyakarta.Diaksesdarihttp:jurnal.pknstan.ac.id/index.php/JMKP/article/vi ew/88/pdf.

Effendy. (2003). Ilmu, Teori dan Filsafat Komunikasi. Bandung: Citra Aditya Bakti.

Ghozali, Imam. (2005). Aplikasi Analisis Multivariate dengan Program SPSS. Badan Penerbit Universitas Diponegoro, Semarang.

Hastuti. (2018). Analisis Penerimaan Negara Bukan Pajak melalui Peraturan Pemerintah Republik Indonesia nomor 12 tahun 2014 pada Balai Taman Nasional Wakatobi. Jurnal Ilmiah Akuntansi Manajemen Vol.1/2, November 2018.

Kamus Besar Bahasa Indonesia (KBBI), Edisi V 0.3.2 Beta (32) tahun 2016-2019, Badan Pengembangan dan Pembinaan Bahasa, Kementerian Pendidikan dan Kebudayaan.

Mahmudi. (2016). Analisis Laporan keuangan Pemerintah Daerah. Yogyakarta: UPP STIM YKPN.

Markus, Muda. (2005). Perpajakan Indonesia Suatu Pengantar. Jakarta: PT Gramedia Pustaka Utama.

Mohammad Mahsun. (2012). Pengukuran Kinerja Sektor Publik.Yogyakarta : BPFE.

Munawir,S. (2012). Analisis Informasi Keuangan, Liberty, Yogyakarta.

Mulyadi, (2007). Sistem Akuntansi, Jakarta :Selemba Empat. 
Mataris, Hilda, Kumba Digdowiseiso, Eko Sugiyanto. (2019). Analisis Kinerja Keuangan Daerah (Studi kasus Kabupaten Magelang).

Mathis, R.L. \& J.H. Jackson. (2006). Human Resource Management: Manajemen Sumber Daya Manusia. Terjemahan Dian Angelia. Jakarta: Salemba Empat.

Nursanti, Masdar Mas'ud, Nur Alam. (2019). Efektivitas dan Pengelolaan Penerimaan Negara Bukan Pajak (Study Kasus pada Kantor Pertanahan Kota Makassar Tahun 2015-2018), Paradoks Jurnal Ilmu Ekonomi, Vol. 2/4,Oktober2019.htXtps://jurnal.fe.umi.ac.id/index.php/PARADOKS/articl e/view/299/205

Prawirosentono,Suyadi. Kebijakan Kinerja Karyawan. Yogyakarta: BPFE,1999.

Peraturan Pemerintah nomor 58 tahun 2020 tentang Pengelolaan PNBP.

Poltak Lijan dan Sinambela Sarton. (2019). Manajemen Kinerja : Pengelolaan, Pengukuran, dan Implikasi Kinerja. Cetakan Kesatu. Depok: PT. RAJA GRAFINDO PERSADA.

Peraturan Pemerintah nomor 82 Tahun 2016 tentang Jenis dan Tarif atas Jenis Penerimaan Negara Bukan Pajak yang Berlaku pada Kementerian Pendidikan dan Kebudayaan.

Rivai dan Basri. (2005). Performance Appraisal: Sistem yang Tepat untuk menilai Kinerja Karyawan dan meningkatkan Daya saing Perusahaan. Rajagrafindo Persada .Jakarta.

Robbins, Stephen P. (1994). Teori Organisasi: Struktur, Desain dan Aplikasi, Alih Bahasa Jusuf Udaya. Jakarta : Arcan.

Rudianto. (2013). Akuntansi Manajemen Informasi untuk Pengambilan Keputusan Strategis. Jakarta: Erlangga.

Salim. Syahrum. (2012). Metodologi Penelitian Kuantitatif. Bandung : CiptaPustaka.

Srimindarti, C. (2006). Balanced Scorecard Sebagai Alternatif untuk Mengukur Kinerja, STIE Stikubank, Semarang. Yogyakarta.

Steers, Richard M. (1977). Efektivitas Organisasi. Seri Manajemen No. 47, Jakarta : Erlangga. 
Sucipto. (2003). "Penilaian Kinerja Keuangan." Jurnal Akuntansi. Universitas Sumatera Utara. Medan.

Sundajaja, Ridwan S dan Inge Barlian. (2003). Manajemen Keuangan. Edisi Keempat. Buku Satu. Literata Lintas Media. Jakarta.

Sugiyono (2015). Metode Penelitian Kombinasi (Mix Methods). Bandung: Alfabeta.

Suryani \& Hendryadi. (2015). Metode Riset Kuantitatif Teori dan Aplikasi pada Penelitian Bidang Manajemen dan Ekonomi Islam. Jakarta: Prenada Media Group.

Sasmito, Anton Wahidin Widjaja. (2018). Analisis Pengaruh Penerimaan Kekayaan Intelektual, Administrasi Hukum Umum dan Keimigrasian Terhadap Penerimaan Negara Bukan Pajak di Lingkungan Kementerian Hukum dan Ham RI, Jurnal Ilmiah Akuntansi Manajemen, Vol. 1/2, November 2018.

Undang-undang nomor 9 tahun 2018 tentang Penerimaan Negara Bukan pajak. 